DOI https://doi.org/10.32837/app.v0i66.667

УДК 324 (477)

\author{
О. О. Онищенко \\ orcid.org/0000-0001-9580-8165
}

аспірант каредри політичних теорій

Національного університету «Одеська юридична академія»

\title{
ТЕНДЕНЦІЇ ТА КРИТЕРІЇ ВПРОВАДЖЕННЯ ВИБОРЧИХ ТЕХНОЛОГІЙ В УКРАЇНІ
}

«Виборчі технології» - поняття відносно нове для українського політичного простору. Україна перейняла значний досвід ведення виборчих кампаній і застосування виборчих технологій у західних країн, які беззаперечно пройшли значний шлях еволюції і розробили чимало технологічних інновацій виборчого процесу.

Еволюція виборчих технологій на теренах України відбувалася в контексті здобуття незалежності та поширення демократичного процесу. Багато технологій, які застосовували у вітчизняному просторі минулого століття, виявилися неефективними саме через трансформаційний перехід до демократичного режиму розвитку держави. 3 огляду на це багатьом політтехнологам України знадобилося багато часу на детальне вивчення та адаптацію західних технологій у нашу систему. Цим пояснюються провальні виборчі кампанії 90-х років в Україні, які методом спроб і помилок намагалися здобути голоси електорату. Демократизація суспільства і створення інституту виборів сприяли формуванню в країні повноцінного політичного ринку (Бебик, 1993, с. 280).

Розвиток виборчих технологій в Україні можна умовно поділити на кілька етапів:

I етап (1991-1998 роки) характеризується неефективністю та інтуїтивним застосуванням окремих виборчих технологій без належної адаптації до вітчизняних умов. Політтехнологи отримали перший досвід ведення виборчої кампанії в умовах конкуренції та демократизації.

II етап (1998-2004 роки) характеризується повним переходом від суто ідеологічного впливу до застосування політичних технологій. Поширюється застосування «чорних» технологій, «чорного» PR-y та використання «адміністративного ресурсу» для здобуття влади. Домінуючою $є$ технологія маніпулювання масовою свідомістю електорату через 3МІ.

III етап (2004 рік-наші дні) характеризується інформаційно-технологічним прогресом, у ході якого з' являються нові технології впливу на електорат та нові методи здобуття голосів виборців. Відбулася остаточна технологізація виборів, перемогу в яких здебільшого здобувають завдяки інформаційним технологіям.

Перші спроби застосування виборчих технологій в Україні починаються з проголошенням державної незалежності 1991 року та скасуванням державної монополії на владу комуністичної партії. Це дало змогу політикам змагатися один з одним за владу у конкурентній боротьбі. На момент здобуття Україною незалежності остаточно ще не сформувалися державні інститути влади, громадянське суспільство, політична культура, система ведення виборчої кампанії, навички електоральної боротьби. Це зумовлено тоталітарним режимом радянської влади, за якого контролювалися усі аспекти життя суспільства та людини. Громадяни були позбавлені політичного вибору та вибору взагалі - «голосування» відбувалося тільки за кандидатів від комуністичної партії за повної відсутності альтернативи і відсутності у людей навичок робити реальний вибір. 3 огляду на це в період здобуття незалежності політтехнологам було важко застосовувати певні виборчі технології, оскільки електорат не вмів робити вибір, коливаючись у наданні своїх переваг між лібералами та представниками комуністичних поглядів.

Крах радянської ідеології розбив примарні мрії багатьох людей, а нові можливості самостійного державного розвитку здавалися громадянам України досить відносними та невизначеними. Саме тому було складно визначити соціальні інтереси більшості населення, політтехнологи не знали, які саме виборчі технології спрацюють, та покладалися на свою політичну інтуїцію. 
Перший етап незалежності України характеризувався широким використанням адміністративного ресурсу, а не виборчих технологій у політичному полі. Це пов'язано із командно-адміністративною системою, на якій базувалася централізація та непорушність радянської влади. Відсутність досвіду застосування виборчих технологій у радянський період позначилася на провальних виборчих кампаніях середини 90-х років незалежної України.

Переломним моментом вважається 1999 рік як новий етап для розвитку політичних технологій. Під час проведення третіх виборів Президента України після здобуття незалежності домінувало гасло: «Виборчі технології проти ідеологій!». Це свідчило про повний відхід від моноідеологічної спрямованості суспільства та транзит до демократичних цінностей і конкурентної боротьби. В таких умовах політики не могли конкурувати, покладаючись виключно на свої сили, вони потребували допомоги політичних консультантів (політтехнологів), які на той момент уже отримали певний досвід ведення виборчої кампанії та починали вчитися правильно застосовувати технології впливу на електорат.

Саме тоді відбувалася перша хвиля «чорних» виборчих технологій. Так, під час виборів 1999 року в кампанії кандидата на посаду Президента України Л. Кучми широко застосовувалися різні маніпулятивні технології у 3MI, контроль інформаційного простору, механізми впливу на свідомість електорату, які і зіграли вирішальну роль у його перемозі. Саме через вдале застосування виборчих технологій з початковим рейтингом у $8 \%$ Л. Кучмі все ж вдалося здобути перемогу на президентських виборах, набравши 36,49\% у першому турі виборів та $56,25 \%$ у другому, отримавши перемогу над своїм головним політичним опонентом від КПУ П. Симоненком.

Політтехнологи зробили акцент на самоідентифікації та позиціонуванні Л. Кучми. Була обрана стратегія боротьби за голоси західної і центральної України на противагу його опонентам, які спиралися на підтримку південно-східної частини електорату. Важливим моментом є «перепозиціонування» іміджу Л. Кучми, бо за часів першої виборчої кампанії (1994 рік) він спирався на підтримку східної частини електорату України. Так, у 1999 році були застосовані технології зміни іміджу кандидата і залякування суспільства «комуністичним минулим». Широко використовувався популізм для несприйняття кандидата-комуніста, яким і був на той час головний політичний опонент Л. Кучми. Тому через «перепозиціонування» - підтримку Західної та Центральної України і критику комуністичного минулого Л. Кучма вдруге здобув бажану перемогу на президентських виборах. Він переміг за рахунок поєднання двох факторів: інтенсивної підтримки Заходу і нейтралітету решти регіонів.

Подальший розвиток виборчих технологій в Україні був досить стрімким і характеризувався постійним впровадженням технологічних «ноу-хау». Парламентські вибори 2002 року продемонстрували підвищення рівня політичної та електоральної культури порівняно 3 минулими роками. На політичній арені перевага електорату надавалася харизматичним типам лідерів - В. Ющенко, Ю. Тимошенко. Виборчі технології того періоду здебільшого були спрямовані на конструювання та підтримку іміджу кандидата, розповсюдження агітаційних матеріалів і на головний «меседж» до виборців. Це було зумовлено запитом електорату до особистих якостей кандидата.

Імідж-білдінг займає провідне місце в електоральному полі України та здатний впливати на вибір громадян. На той час громадяни надавали перевагу тим політичним партіям, на чолі яких стояв сильний і харизматичний лідер, здатний об'єднати країну по лінії: Схід - Захід і стати «батьком нації». Найбільшою популярністю користувалися іменні партії та блоки (БЮТ - Блок Юлії Тимошенко; Блок Володимира Литвина). Саме тому головним завданням перед політтехнологами було якомога краще продумати та побудувати імідж своєму кандидату, який буде втілювати риси сильної, розумної людини-лідера. Уся виборча кампанія будувалася навколо іміджу однієї людини, партії стали персоніфікованими та асоціювалися із конкретною персоною. Особисті якості окремих політичних лідерів того часу слугували для багатьох українських виборців основою для їх електорального вибору (Бебик, 2001, с. 76-79).

Другою характерною рисою парламентських виборів 2002 року стало застосування «чорних» технологій. Серед них найчастіше використовувалася технологія «клонування» партій і кандидатів. Постійно реєструвалися так звані «партії-двійники». Скандальним прикладом 
є спроба О. Ржавського зареєструвати блок «За Ющенка», проте за рішенням Верховного Суду України зробити це йому не дозволили (Бебик, 2001, с. 85-86). Експерти Українського незалежного центру політичних досліджень нарахували 119 осіб, які брали участь в реєстрації «кандидатів-двійників» у 46 округах на парламентських виборах 2002 року.

Набула популярності практика використання адміністративного ресурсу на парламентських виборах 2002 року як основного механізму владного впливу для досягнення своєї мети. Політтехнологи у виборчих кампаніях своїх кандидатів активно використовували технології «чорного» PR-y. Поширення таких технологій $\epsilon$ закономірним етапом становлення електоральної культури в країнах перехідного типу. А. Баронін наголошує, що в Україні, як і на всьому пострадянському просторі, невміння суб'єктів виборчих кампаній користуватися «білим PR-ом» призвело до переоцінки ролі «чорного PR-y» (Баронін, 2006, с. 85).

Важливим етапом у розвитку виборчих технологій стали президентські вибори 2004 року та події «помаранчевої революції», які відкрили для українського політичного поля нові форми та методи ведення боротьби за голоси виборців. Аналіз саме цих виборів показує руйнівну силу застосування «чорних» технологій і маніпуляції свідомістю громадян. Боротьба велася між двома основними кандидатами на посаду Президента України: між В. Ющенком і В. Януковичем. Виборчі технології того часу застосовувалися для розшарування українського суспільства на два ворогуючих табори за принципом прихильності до кандидата та його ідей. Так, В. Януковича позиціонували як кандидата від Сходу України, а В. Ющенка - від Заходу. За цим критерієм і ділилося суспільство на два антагоністичні блоки: Схід - Захід. 3 боку політичних технологів це був умисний розкол нації з метою чітко відділити «своїх» від «чужих». Критеріями поділу суспільства стали основні політичні ідеї двох кандидатів, які були полярними однин щодо одного. Серед таких критеріїв було мовне питання, зовнішньо-політична орієнтація держави (Свросоюз чи Митний союз), релігійні питання (УПЦКП чи УПРМП), культурно-історичні суперечності.

Піднімалися на розгляд питання, які чітко могли розділити суспільство на два ворогуючі табори. Імідж В. Ющенка був побудований на основі українського патріотизму, ідей євро-спрямованості, як шанувальника культурно-історичної спадщини України, образ справжнього патріота та інтелігента. Імідж В. Януковича був зав' язаний на підтримці Східно-Південної частини України. Він відстоював ідеї захисту російської мови, загальної культурної спадщини із Росією та країнами СНГ, тісні економічні зв' язки з Російською Федерацією. Головним завданням політтехнологів того часу було створити ідентифікацію між кандидатом і виборцем для того, щоб змусити виборця відстоювати «свого» кандидата як самого себе.

У результаті політичної боротьби 2004-го року відбулися загострення відносин між регіонами України по лінії Західно-Північна та Центральна Україна проти південно-східної ії частини. В результаті технологій маніпуляції та умисного розколу суспільства на два табори відносини ворожості один до одного досягли найвищої точки.

Серед експертів тривають дискусії стосовно того, чи була «помаранчева революція» наслідком застосування виборчих технологій, чи це була акція народного волевиявлення. Революція 2004 року була переломним моментом у процесі переходу України до демократії та новим етапом становлення громадянського суспільства (Кочубей, 2006, с. 130). «Помаранчева революція» 2004 року засвідчила перехід українського суспільства до нового рівня політичної культури та нових методів ведення виборчої кампанії із застосуванням інноваційних технологій. Важко переоцінити значення революції 2004-го року для розвитку демократичних цінностей нашої держави. На думку теоретиків транзитології, процес демократизації в перехідних суспільствах складається з двох послідовних переходів, перший з яких призводить до формування демократичних інститутів, другий - до укорінення демократичних цінностей у політичній культурі, що забезпечує ефективне функціонування демократичного режиму (Буркут, 2009, с. 234).

Третій етап розвитку виборчих технологій, починаючи з парламентських і місцевих виборів 2006 року, характеризується появою на політичній арені нових політичних акторів $\mathrm{i}$ зменшенням використання «чорних» технологій порівняно з виборами 2004-го року. Зміни були пов' язані із запровадженням нової конституційної реформи та пропорційної виборчої системи. Нововведення потребували перегляду на ведення виборчої кампанії та зміни арсе- 
налу технологій. Лібералізація ЗМІ призвела до зміни впливу масової інформації на свідомість електорату (ці зміни збереглися протягом парламентських виборів 2007 року та президентських 2009-2010-х років).

На виборах 2006-го року провалилися партії, які були створені з метою «технологічного» проекту, переслідували власні політичні цілі. Сформувався певний рівень політичної культури серед населення: вже не обиралися ті партії, які були просто чиїмось проектом. Партії вже не опиралися лише на технології маніпуляції, оскільки населення України почало ретельніше відбирати політичні партії та їх кандидатів. 3' явилася необхідність застосування «білих» технологій і перемога у більш чесній конкурентній боротьбі. Рівень політичної культури підвищив пильність електорату щодо застосування у політиці «заборонених прийомів». Президентські вибори 2004 року та розкол суспільства на два ворогуючих табори дали зрозуміти усім всю сутність «брудних» технологій і їх наслідки для країни.

Ще одним із доказів залежності сучасних виборчих кампаній від засобів масової комунікації в Україні можна вважати відсоток від загального виборчого фонду, який витрачається політичними силами за виборчий період. Проаналізувавши фінансові звіти рейтингових політичних партій після позачергових виборів народних депутатів 2014 року, складається картина загальних витрат на мас-медіа: політична партія «Народний фронт» віддала за використання 3МК 81,16\% усього виборчого фонду, Всеукраїнське об'єднання «Свобода» - 87,21\%, політична партія «Опозиційний блок» - 94,06\%, Всеукраїнське об'єднання «Батьківщина» 90,77\%, Радикальна партія Олега Ляшка - 99,02\%, партія «Блок Петра Порошенка» - 88,54\%. Такі показники доводять, що політичні сили покладають велику надію саме на можливості та особливості засобів масової комунікації у процесі виборчої кампанії.

Аналіз виборчих кампаній 2004-2010-х років свідчить про те, що в Україні створюються необхідні умови для переходу політтехнологами на використання «білих» технологій маркетингового типу та поступове відмирання «брудних» технологій як менш дієвого та протизаконного механізму досягнення мети. Ще не закінчилося становлення виборчих технологій в Україні, потрібно ще багато часу для остаточного формування громадянського суспільства, політичної культури, рівня довіри до органів державної влади.

Нині на перший план виходять адресні технології комунікації із виборцями. На парламентських виборах 2006-2007 років перевагу отримали саме ті партії, які приділяли найбільше часу зустрічам із електоратом і отримували найбільшу кількість голосів від виборців. На президентських виборах 2009-2010 років ця технологія знайшла більш широке використання, коли спеціально найняті люди заходили до кожного будинку, щоб особисто переконати виборців віддати свій голос саме за їх кандидата.

Поряд із демократизацією виборчого процесу все ж застосовуються «сірі» технології у вигляді «підкупу виборців» через роздачу подарунків, харчів, речей першої необхідності. Іноді йдеться про непрямий підкуп, але технологія мережевого маркетингу (роздачі подарунків) дає свій результат. В умовах економічної нестабільності, фінансової кризи та неспроможності багатьох громадян придбати собі зайві речі першої необхідності роздача «призів» і «подарунків» впливає на результат виборів.

Домінуючою технологією був імідж-білдинг - просування власного іміджу та протиставлення себе опоненту. Відбувається створення іміджу політика на фоні висвітлення негативних моментів опонента - технологія негативного підходу. В результаті виборець віддає перевагу кандидату з більш досконалою, хоч іноді і чисто віртуально створеною репутацією. Це засвідчили президентські та парламентські вибори в Україні 2019 року. Щоправда штучно створені рейтинги досить швидко зменшуються.

Таким чином, за роки своєї незалежності Україна пройшла складний та інтенсивний розвиток формування та впровадження виборчих технологій, який можна описати гаслом президентських виборів 1999 року: «Виборчі технології проти ідеології!». Нині ринок політичних технологій в Україні значно розширився, щоденно з'являються нові інструменти боротьби за голоси електорату, поступово відмирають «чорні» технології. Лише укріплення громадянського суспільства та підвищення рівня політичної культури в Україні посприяють впровадженню сучасних ефективних політичних технологій у подальшому. 


\section{Лimepamypa}

Баронін А.С. Правила гри у грі без правил. Передвиборчі технології в Україні. Прага : Гранда, 2006. 188 c.

Бебик В.М. Як стати популярним, перемогти на виборах та утриматися на політичному олімпі. Київ : Абрис, 1993. 128 с.

Бебик В.М. Менеджмент виборчої кампанії: ресурси, технології, маркетинг : навч.-метод. посіб. К. : МАУП, 2001. 214 с.

Буркут І.Г. Виборчі технології: регіональний досвід. Чернівці : Букрек, 2009. 240 с.

Кочубей Л.О. Виборчі технології: політичний аналіз (на прикладі виборів до парламенту сучасної України) : монографія. Київ : Юридична думка, 2006. 280 с.

\section{References}

Baronin A.S. (2006) Pravyla hry u hri bez pravyl. Peredvyborchi tekhnolohii v Ukraini [Rules of the game without rules. Pre-election technologies in Ukraine]. Praha : Granda, 2006 [in Ukrainian].

Bebyk V.M. (1993) Yak staty populiarnym, peremohty na vyborakh ta utrymatysia na politychnomu olimpi [How to become popular, win elections and stay on the political Olympus]. K. : Abrys, 1993 [in Ukrainian].

Bebyk V.M. (2001) Menedzhment vyborchoi kampanii: resursy, tekhnolohii, marketynh : navch.-metod. posib [Election campaign management: resources, technologies, marketing: a textbook]. K. : MAUP, 2001 [in Ukrainian].

Burkut I.H. (2009) Vyborchi tekhnolohii: rehionalnyi dosvid [Electoral technologies: regional experience]. Chernivtsi : Bukrek, 2009 [in Ukrainian].

Kochubei L.O. (2006) Vyborchi tekhnolohii: politychnyi analiz (na prykladi vyboriv do parlamentu suchasnoi Ukrainy) : monohrafiia [Electoral technologies: political analysis (on the example of elections to the parliament of modern Ukraine): a textbook]. K. : Yurydychna dumka, 2006 [in Ukrainian].

\section{Анотація}

Онищенко О. О. Тенденції та критерії впровадження виборчих технологій в Україні. - Стаття.

У статті розглянуто сутність тенденцій становлення виборчих технологій на теренах України, виділені основні етапи розвитку виборчих технологій, проаналізовано застосування виборчих технологій під час електоральних кампаній в Україні. Охарактеризовано основні різновиди та моделі виборчих технологій, обгрунтовано застосування іміджевих політичних технологій. Іміджеві технології є надскладним феноменом, який створюється на основі поєднання діяльнісних, психологічних, інформаційних та емоційно-комунікативних чинників. Це поєднання раціональних та ірраціональних чинників впливу на масову свідомість, які передбачають поєднання політичних, психологічних і соціологічних наукових досліджень.

Політичний імідж - це сукупність уявлень, сприйняття і переконань, які має індивід або група індивідів про різні політичні явища або товари. Поняття іміджу здебільшого відноситься до конкретної людини, але може розповсюджуватися на групу осіб, організацію, товар. За допомогою іміджу створюється яскравий образ у масовій свідомості, який запам'ятовується та схиляє симпатії електорату до політика чи партії. У політиці вдало сформований імідж кандидата - це запорука перемоги на виборах, бо в умовах нинішньої політичної культури увага потенційного виборця концентрується саме на особистості, яка представляє певну політичну силу, тому вдало підібраний образ кандидату гарантує високі рейтинги.

У статті окреслено шкалу питань актуальності виборчих технологій під час електоральних кампаній, показані якісні зміни виборчих технологій, застосування інновацій у період електоральної боротьби за часів незалежності держави. Висвітлено питання використання «чорних» і «білих» PR-технологій, окреслено морально-етичний вибір політиків для досягнення власної мети. Досліджено вплив громадянського суспільства та рівень політичної культури на розвиток виборчих технологій. Проаналізована «помаранчева революція» в Україні, яка стала переломним моментом у веденні політичної боротьби між конкуруючими партіями.

Ключові слова: технології, виборчі технологіі, політичні технології, електорат.

\section{Summary}

Onyschenko O. O. Tendencies and criteria of formation of election technologies in Ukraine. - Article.

The article considers the essence of tendencies of formation of election technologies on the territory of Ukraine, highlights the main stages of development of election technologies and analyzes the application of election technologies during election campaigns in Ukraine. The main varieties and models of electoral technologies are characterized, the application of image political technologies is substantiated. 
Image technologies are an extremely complex phenomenon, which is created on the basis of a combination of activity, psychological, informational and emotional - communicative factors. It is a combination of rational and irrational factors influencing the mass consciousness, which involve a combination of political, psychological and sociological research. Political image is a set of ideas, perceptions and beliefs that an individual or group of individuals has about various political phenomena or goods. As a rule, the concept of image refers to a specific person, but can apply to a group of people, organization, product. With the help of the image, a bright image is created in the mass consciousness, which is remembered and arouses the sympathy of the electorate for the politician or the party.

In politics, a well-formed image of a candidate is a guarantee of victory in elections, because in the current political culture, the attention of a potential voter is focused on a person who represents a certain political force, so a well-chosen image of the candidate guarantees high ratings. The scale of issues of relevance of election technologies during election campaigns is outlined. The article shows the qualitative changes in electoral technologies and the application of innovations during the electoral struggle during the independence of the state. The issue of using "black" and "white" PR technologies is covered, the moral and ethical choice of politicians to achieve their own goal is outlined. The influence of civil society and the level of political culture on the development of electoral technologies is studied. The "Orange Revolution" in Ukraine, which became a turning point in the political struggle between rival parties is analyzed.

Key words: technologies, election technologies, political technologies, electorate. 